\title{
Magdalena Żakowska
}

Katedra Europy Środkowej i Wschodniej

Wydział Studiów Międzynarodowych i Politologicznych

Uniwersytet Łódzki

\section{ROSYJSCY NIEMCY NA POGRANICZU KULTUR STRATEGIE TOŻSAMOŚCIOWE „PÓŹNYCH PRZESIEDLEŃCÓW"Z ROSJI W RFN}

Mocno upraszczając, dzieje współczesnej niemieckiej mniejszości etnicznej w Rosji sięgają manifestu Katarzyny II z 1763 r. zachęcającego cudzoziemskich kolonistów do osiedlania się w imperium carów ${ }^{1}$. Pierwsza fala osadników została skierowana na stepy nadwołżańskie, druga - na północne wybrzeża Morza Czarnego. W 1804 r. Aleksander I wydał następny manifest. Pod jego wpływem do Rosji przybyli kolejni koloniści niemieccy, osiedlając się w Besarabii, nad Morzem Azowskim, na Krymie. Na fali polityki rusyfikacyjnej ostatnich Romanowów, od lat siedemdziesiątych XIX w. stopniowo zaczęto zrównywać ich w zakresie praw i obowiązków z rosyjskimi chłopami. W 1914 r. przebywało w Rosji prawie 2,5 mln Niemców. Pod względem liczebności plasowali się na dziewiątym miejscu wśród mniejszości narodowych imperium. Ponad trzy czwarte $\mathrm{z}$ nich stanowili chłopi ${ }^{2}$.

Po przejęciu władzy przez bolszewików, w ramach strategii pozyskiwania mniejszości narodowych, w latach dwudziestych XX w. utworzono szereg niemieckich rejonów autonomicznych. Największym z nich była Autonomiczna Socjalistyczna Republika Radziecka Niemców Nadwołżańskich, która powstała w 1924 r. Już jednak pod koniec tego dziesięciolecia wielu niemieckich „kuła-

\footnotetext{
${ }^{1}$ Początki obecności Niemców w Rosji sięgają jeszcze głębiej w przeszłość, bo drugiej połowy XV w., kiedy to Iwan III Srogi (1462-1505), później zaś jego syn i następca, Wasyl III (1505-1533), starał się pozyskać zagranicznych oficerów, administratorów, budowniczych, lekarzy, rzemieślników i nauczycieli do przeprowadzenia reform wewnętrznych w państwie, przezwyciężenia techniczno-cywilizacyjnego zacofania kraju, umocnienia władzy centralnej i ograniczenia wpływu bojarów. Mnóstwo cudzoziemców pojawiło się zwłaszcza w Moskwie, gdzie przeznaczono dla nich specjalną dzielnicę na przedmieściu, której mieszkańcy byli zwolnieni z ciężarów feudalnych i korzystali z gospodarczych przywilejów - Niemiecką Słobodę, zwaną Kokuj, położoną nad rzeką o tej samej nazwie. Por. M. Żakowska, Niemcy w Rosji do końca XIX w., [w:] Oblicza Wschodu. Religia, ideologia, polityka, gospodarka, red. M. Broda, M. M. Dziekan, Warszawa 2004, s. 39-57.

${ }^{2}$ Por. A. Eisfeld, Die Russlanddeutschen, München 1992, s. 10-16; T. Lebioda, Niemcy rosyjscy, „Przegląd Zachodni” 1997, nr 1, s. 20-22.
} 
ków" trafiło do łagrów, a cała ziemia uprawna republiki nadwołżańskiej - do kołchozów. Od 1935 r. władze radzieckie stopniowo likwidowały niemieckie rejony autonomiczne. Po agresji Hitlera, w sierpniu 1941 r., władze ZSRR deportowały prawie 950 tys. Niemców żyjących na obszarach na zachód od Uralu do tzw. specjalnych osiedli na Syberii i w Kazachstanie, będących w istocie obozami pracy przymusowej. Dopiero odwilż w stosunkach ZSRR-RFN zaowocowała likwidacją wspomnianych „osiedli” w 1955 r. ${ }^{3}$ W 1964 r. radzieccy Niemcy zostali oficjalnie oczyszczeni z zarzutu o kolaborację z Hitlerem, a w 1972 r. zniesiono wobec nich ograniczenia w wyborze miejsca zamieszkania ${ }^{4}$.

W 1989 r. w ZSRR żyło ponad 2 mln osób przyznających się do narodowości niemieckiej, głównie w radzieckich republikach środkowoazjatyckich. Dwie trzecie z nich było zatrudnionych jako pracownicy umysłowi, jedna czwarta pracowała w rolnictwie. Na początku lat dziewięćdziesiątych XX w. sytuacja gospodarcza rosyjskich Niemców nie różniła się specjalnie od średniej radzieckiej, nawet w niektórych aspektach była od niej nieco lepsza (np. pod względem liczby wykupionych mieszkań). W lipcu 1991 r. władze radzieckie restytuowały niemiecki rejon autonomiczny w Kraju Ałtajskim5, zaś w 1992 r. w zachodniosyberyjskim

\footnotetext{
${ }^{3} \mathrm{Na}$ marginesie należy wspomnieć również o innych grupach ludności niemieckiej, obecnych w ZSRR przed lub w dobie negocjacji niemiecko-radzieckich w Moskwie w 1955 r. Chodzi o obywateli Republiki Weimarskiej i III Rzeszy, przybyłych do Kraju Rad w dwudziestoleciu międzywojennym i w czasie II wojny światowej. Po traktacie niemiecko-radzieckim w Rapallo (1922) Niemcy zaczęli na terenie Rosji Radzieckiej szkolić swoje kadry wojskowe i przysłali na jej terytorium setki specjalistów przeprowadzających w Kraju Rad badania w dziedzinie technik wojskowych. Współpraca ta trwała owocnie aż do 1933 r., gdy po objęciu władzy przez nazistów niemieccy wojskowi i eksperci w większości powrócili do Niemiec. Lata dwudzieste, szczególnie jednak początek lat trzydziestych XX w. wiąże się z kolei z nasiloną imigracją do ZSRR członków Niemieckiej Partii Komunistycznej. Ojczyzna światowego proletariatu najpierw udzieliła im azylu, później jednak, w szczytowym okresie czystek stalinowskich (lata 1937-1938), 70\% z nich skazała na śmierć lub kary więzienia pod zarzutem przestępstw politycznych. Z kolei w okresie II wojny światowej radzieckie obozy jenieckie, funkcjonujące na zasadach obozów pracy, zasiliło ponad 3 mln niemieckich jeńców wojennych. Przeszło $1 \mathrm{mln}$ z nich zmarło, pozostali zaś byli stopniowo uwalniani w latach 1945-1956. Analogiczny los stał się udziałem ok. 1,5 mln niemieckich cywilów, schwytanych na obszarze ZSRR lub, po wojnie, w radzieckiej strefie okupacyjnej. Znalazło się wśród nich kilka tysięcy niemieckich naukowców, którzy zostali wprzężeni przez władze radzieckie do badań nad unowocześnieniem radzieckiego przemysłu zbrojeniowego. W. Dobrzycki, Historia stosunków międzynarodowych $w$ czasach nowożytnych 1815-1945, Warszawa 1996, s. 362-363; R. Müller, Menschenfalle Moskau. Exil und stalinistische Verfolgung, Hamburg 2001; A. Hilger, Deutsche Kriegsgefangene in der Sowjetunion, 1941-1956. Kriegsgefangenenpolitik, Lageralltag und Erinnerung, Essen 2000; Ch. Mick, Forschen für Stalin. Deutsche Fachleute in der sowjetischen Rüstungsindustrie 1945-1958, München 2000.

${ }^{4} \mathrm{~B}$. Schmitt, Etnische Identitat und gesellschaftliche Integrationsprobleme im Wandel der Zeit, „Deutsche Studien“ 1997, nr 3, s. 284; T. Lebioda, Niemcy rosyjscy, s. 27-30; R. H. Walth, Auf der Suche nach Heimat. Die Russlanddeutschen. In search of home. The Germans from Russia, Dulmen 1991, s. 38-39; M. Geissl, B. Mai, Die Deutschen im Osten, Berlin-Bonn 1988, s. 12-20.

${ }^{5}$ Wcześniej istniał on w latach 1927-1938. T. Lebioda, Niemcy rosyjscy w polityce RFN na tle ich znaczenia w Rosji i relacjach niemiecko-rosyjskich w latach 1763-2003, Wrocław 2004, s. 281.
} 
rejonie omskim utworzono niemiecki okręg narodowy Asowo. Największa organizacja reprezentująca Niemców w Rosji, „Odrodzenie”, od końca lat osiemdziesiątych XX w. walczy o restytucję republiki nadwołżańskiej'.

Przyszłość Niemców w Rosji jest niepewna, kształtowana przez alternatywę - zostać czy wyjechać, wybrać emigrację czy liczyć na odbudowę struktur autonomicznych. Za tym ostatnim rozwiązaniem optuje wprawdzie reprezentująca mniejszość niemiecką w krajach WNP organizacja „Odrodzenie”. W myśl jej założeń odtworzenie stanu sprzed deportacji miałoby stworzyć z jednej strony fundament dla poprawy perspektyw życiowych Niemców mieszkających na obszarach WNP i zatrzymać postępującą asymilację oraz wynarodowienie, z drugiej zaś stanowić alternatywę dla dominującej i przybierającej na sile emigracji tej ludności do RFN. Wszystko wskazuje jednak na to, że nawet stopniowe odtwarzanie niemieckich struktur autonomicznych nie zahamuje w ciągu najbliższych lat pragnienia przesiedlenia się tej ludności do „kraju przodków”.

Do „przebudzenia narodowego" rosyjskich Niemców po latach intensywnej sowietyzacji doszło dopiero w atmosferze głasnosti. Wówczas zaczęli oni upowszechniać prawdę o „białych plamach” swej przed- i powojennej historii - o istniejącej przed $1941 \mathrm{r}$. autonomicznej republice nadwołżańskiej, deportacji na Syberię, obozach pracy - oraz domagać się pełnej rehabilitacji, w tym również przywrócenia im autonomii. Wtedy też dopiero, wraz z pojawieniem się szans na „repatriację” do RFN, rosyjscy Niemcy zaczęli ujawniać, czy wręcz konstruować, swą niemiecką tożsamość. Znalazło to odzwierciedlenie w deklaracjach do spisu powszechnego z 1989 r., zgodnie z którym w ZSRR przebywało ponad $2 \mathrm{mln}$ Niemców, oraz w fakcie, że w kolejnym dziesięcioleciu trend związany z ,ppowrotem do niemieckości" przybrał na sile. W latach dziewięćdziesiątych liczba osób uważających się za Niemców doszła do ok. 3,5 $\mathrm{mln}^{8}$.

Pamięć historyczna rosyjskich Niemców najczęściej wiąże się z wydarzeniami osobiście doświadczonymi lub zasłyszanymi od członków rodziny i jest wybiórcza. Wśród przedstawicieli najmłodszego pokolenia często jedynie w zdawkowym stopniu obejmuje ona wiedzę o autonomicznej republice nadwołżańskiej, a nawet o prześladowaniach, które stały się udziałem tej grupy etnicznej w czasie II wojny światowej i w okresie powojennym. Z drugiej jednak strony,

${ }^{6}$ T. Lebioda, Niemcy rosyjscy, s. 38-43; B. Dietz, Zwischen Anpassung und Autonomie. Russlanddeutsche in der vormaligen Sowjetunion und in der Bundesrepublik Deutschland, Berlin 1995, s. 45-49, 78-79, 86.

7 B. Dietz, Zwischen ..., s. 39.

${ }^{8}$ Por. tamże, s. $20-60$. 
aż36\% Niemców przybyłych do RFN z zachodniej Syberii i z Kazachstanu, ankietowanych przez Barbarę Dietz w 1991 r., było w stanie odpowiedzieć na pytanie, $\mathrm{z}$ jakich krain niemieckich przybyli do Rosji ich przodkowie w XVIII lub XIX w. ${ }^{9}$

Większość niemieckich kolonistów przez stulecia żyła w carskiej Rosji w zwartych, monoetnicznych osiedlach, pielęgnując swój język, tradycje i kulturę. Przebywając w zamkniętych homogenicznych wspólnotach, często jedynie w niewielkim stopniu integrowali się oni z miejscową ludnością, nie uczyli się języka rosyjskiego. Procesy asymilacyjne większości rosyjskich Niemców zostały przyspieszone, wręcz wymuszone, przez ,antynacjonalistyczną” i ,,antyfaszystowską" politykę władz ZSRR. Kluczowym wydarzeniem, które przypieczętowało ich los, był wydany w sierpniu $1941 \mathrm{r}$. dekret o przesiedleniu Niemców żyjących w rejonie Wołgi ${ }^{10}$. W jego wyniku rosyjscy Niemcy zostali wyrwani z ojczystych siedzib, rozproszeni po azjatyckiej części ZSRR i zmuszeni do wyrzeczenia się rodzimej kultury.

Sytuację Niemców rosyjskich w pierwszych dziesięcioleciach po II wojnie światowej pogarszała niechęć lokalnej, radzieckiej administracji oraz negatywne nastawienie sąsiadujących z nimi grup etnicznych. Największą antypatią darzyli ich Rosjanie, nazywając faszystami, mniejszą - autochtoniczne ludy Azji Środkowej, widząc w nich przede wszystkim obcych, mniej zaś wrogów. Okoliczności te wpłynęły na niechęć Niemców do przyznawania się do własnej etniczności i do posługiwania się rodzimym językiem. O ile spośród Niemców, którzy w $1959 \mathrm{r}$. zostali ujęci w spisie narodowościowym, $75 \%$ podało niemiecki jako język ojczysty, o tyle w 1970 r. było to $66,8 \%$, w 1979 r. $-57,7 \%$, a w 1989 r. już tylko $48,7 \%$, a osób umiejących się nim faktycznie posługiwać było jeszcze mniej ${ }^{11}$. Z badań przeprowadzonych w $1991 \mathrm{r}$. wynikało, że język niemiecki ostał się praktycznie jedynie w odciętych od świata niemieckich wioskach syberyjskich i azjatyckich oraz wśród starszego pokolenia ${ }^{12}$. Według spisu ludności z 1979 r. w ZSRR żyło ponad 1936000 Niemców, zajmując 14. miejsce pod względem liczebności spośród ponad 100 narodów imperium. W przeciwieństwie do innych narodów nie uwzględniono ich jednak jako mniejszość narodową w Wielkiej Encyklopedii Radzieckiej ${ }^{13}$.

${ }^{9}$ Tamże, s. 42. Na tę ostatnią okoliczność ma wpływ zapewne fakt, że przedstawienie udokumentowanej genealogii rodzinnej, sięgającej czasów wychodźstwa z ziem niemieckich, podobnie jak udowodnienie nieprzerwanego kultywowania tradycji i obyczajowości wyniesionej stamtąd jest jednym z kryteriów wpływających na możliwość emigracji do RFN w charakterze „późnych przesiedleńców”.

${ }^{10}$ E. Schoppert, Wir werden Staub im Wind, [w:] Russlanddeutsche - woher? wohin?, red. J. Warkentin, Berlin 1992, s. 80.

${ }^{11}$ T. Lebioda, Niemcy rosyjscy, s. 37.

${ }^{12}$ B. Dietz, Zwischen ..., s. 42.

${ }^{13}$ Tamże, s. 32. 
Proces sowietyzacji rosyjskich Niemców w trakcie oraz po II wojnie światowej miał początkowo odgórny, wymuszony i sztuczny charakter. W perspektywie lat i dziesięcioleci okazał się jednak niezwykle skuteczny. Co więcej, proces ,zruszczania” i „sowietyzowania” „rosyjskich Niemców” postępował stopniowo również oddolnie, obejmując zwłaszcza młodsze pokolenia, urodzone i wychowane po wojnie ${ }^{14}$. Język niemiecki przestał być dla nich ,językiem serca”. Czynnikami spajającymi „diasporę" niemiecką w WNP są język i kultura rosyjska oraz mentalność „,radziecka”. Jedna z anegdot dotyczących rosyjskich Niemców przytacza następujący dialog: ,- Как у тебя с немецким? - Как у собаки. Все понимаю, только сказать ничего не могу" ${ }^{\prime \prime}$.

Rose Ausländer, niemieckojęzyczna poetka pochodzenia żydowskiego, urodzona w Czerniowcach należących do Austro-Węgier, w emigracyjnym wierszu Mutterland (1978), pisała o rodzimym języku jako jedynej ojczyźnie dostępnej ludziom wykorzenionym:

\author{
Mein Vaterland ist tot \\ sie haben es begraben \\ im Feuer \\ Ich lebe \\ im meinem Mutterland \\ Wort ${ }^{16}$.
}

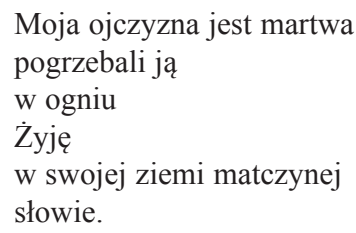

Dla rosyjskich Niemców, którzy wyemigrowali do RFN, to język rosyjski stanowi taką właśnie „ziemię matczyną”. Bardziej afirmacyjny, choć mniej charakterystyczny, jest sposób myślenia Borisa Rauschenbacha, wybitnego fizyka, będącego jednym z ojców radzieckiej kosmonautyki i równocześnie aktywnego działacza organizacji Niemców rosyjskich „Odrodzenie”. Pisząc o swych rodakach, stwierdził: „Żyjąc w Rosji staliśmy się społecznością o własnej historii, kulturze, języku. Zachowaliśmy wiele z tego, co wynieśliśmy z Niemiec, wiele dodaliśmy też od siebie. Jesteśmy dziećmi dwóch narodów, niemieckiego i rosyjskiego; na tym polega nasza wyjątkowość i wartość, jaką mamy do zaoferowania Rosji i Niemcom"17.

${ }^{14}$ T. Constable, Zwischen allen Stühlen...Von der Schwierigkeit, in Russland eine deutsche Identität zu definieren, [w:] Bildung und nationale Identität aus russischer und russlanddeutscher Perspektive, red. G. Schmidt, M. Krüger-Potratz, Münster 1999.

${ }^{15}$ A. Reiser, R. Schultz, 99 Anekdoten von Aussiedlern, Detmold 2005, s. 42. Por. H. Frank, Zur sprachlichen Entwicklung der deutschen Minderheit in Russland und in der Sowjetunion, Frankfurt am Main-Berlin-Bern-New York-Paris-Wien 1992, s. 160.

${ }^{16} \mathrm{Ch}$. Eyselein, Russlanddeutsche Aussiedler verstehen. Praktisch-theologische Zugänge, Leipzig 2006, s. 342.

${ }^{17}$ B. Dietz, Zwischen ..., s. 130. 


\section{Niemiecka polityka ,przesiedleńcza" ${ }^{18}$}

Stosowana w RFN zasada ius sanguinis stanowi, że Niemcem jest każdy człowiek, który z pochodzenia należy do narodu niemieckiego. Artykuł 116 niemieckiej konstytucji z 1949 r. głosi: „Niemcem w sensie niniejszej ustawy zasadniczej jest ten [...], kto ma niemiecką przynależność państwową lub został na obszarze Rzeszy Niemieckiej, pojmowanym według stanu z 31 grudnia 1937 r., przyjęty jako uchodźca lub wypędzony o niemieckiej przynależności narodowej albo jako jego współmałżonek czy potomek" ${ }^{\prime 19}$. Ustawa o wypędzonych z $1953 \mathrm{r}$. uznaje za członka narodu niemieckiego każdego, „kto w swej ojczyźnie uznał się za Niemca, jeśli potwierdzają to określone znamiona, takie jak pochodzenie, język, wychowanie, kultura"20.

W okresie powojennym, praktycznie aż do końca lat osiemdziesiątych, władze RFN prowadziły politykę nakierowaną na ułatwianie i upraszczanie procedur repatriacyjnych wobec etnicznych Niemców. Oprócz aspektu humanitarnego miała ona również kontekst pragmatyczny. Wpisywała się w szeroko zakrojoną politykę imigracyjną, nastawioną na pozyskiwanie gastarbeiterów do prężnie rozwijającego się przemysłu RFN ${ }^{21}$.

W latach powojennych RFN nawiedzały kolejne fale emigrantów ze wschodu. Między 1950 a 1985 r. przybyło tam ponad 1,2 mln „przesiedleńców” i „późnych przesiedleńców" głównie z Polski i ZSRR, lecz także z Czechosłowacji i Rumunii ${ }^{22}$. Choć za czasów ZSRR rosyjscy Niemcy mieli stosunkowo ograniczone możliwości „repatriacji”, na początku lat dziewięćdziesiątych XX w. stali się najliczniejszą grupą napływową w RFN, nie tylko w skali „przesiedleńców”. Między 1988 a 2003 r. przybyło ich do Niemiec ok. 2,8 $\mathrm{mln}^{23}$, przy czym

18 Niemieckimi odpowiednikami stosowanych przeze mnie terminów „przesiedleniec” i „późny przesiedleniec” są Aussiedler i Spätaussiedler. W dosłownym thumaczeniu znaczą one: „wysiedleniec/wysiedleńcy” i „późny wysiedleniec/ późni wysiedleńcy”. W tekście konsekwentnie posługuję się terminologią wspomnianą wyżej z uwagi na jej większą adekwatność w praktyce i w świadomości potocznej. Aussiedler znaczy po niemiecku „,wysiedleniec/wysiedleńcy”, w sensie prawnym nie odnosi się jednak do Niemców „wysiedlonych” czy też „,wypędzonych” ze stron rodzinnych w trakcie i po zakończeniu II wojny światowej, a do osób niemieckiego pochodzenia z krajów Europy Środkowej i Wschodniej przybyłych do RFN w okresie od 1953 r. do końca lat siedemdziesiątych XX w. Analogicznie przedstawia się sytuacja z kategorią Spätaussiedler oznaczającą literalnie „późnego wysiedleńca/późnych wysiedleńców”, w rzeczywistości zaś tzw. etnicznych Niemców, przybyłych dobrowolnie do RFN z państw (byłego) bloku wschodniego $\mathrm{w}$ okresie od początku lat osiemdziesiątych XX w.

${ }^{19}$ U. Altermatt, Sarajewo przestrzega. Etnonacjonalizm w Europie, thum. G. Sowiński, Kraków 1998, s. 187.

${ }^{20}$ Tamże.

${ }^{21}$ A. Trzcielińska-Polus, ,Wysiedleńcy” z Polski w Republice Federalnej Niemiec $w$ latach 1980-1990, Opole 1997, s. 130.

${ }^{22}$ U. Altermatt, Sarajewo przestrzega., s. 186.

${ }^{23}$ B. Dietz, Zwischen ..., s. 110. 
w 2002 r. na jednego ,pełnowartościowego" repatrianta przypadało jego czworo nieniemieckojęzycznych, najczęściej rosyjskich, krewnych. Obecnie liczbę „,późnych przesiedleńców" $\mathrm{z}$ byłego ZSRR szacuje się na ok. $3 \mathrm{mln}$ osób ${ }^{24}$.

Kres omawianym tendencjom przyniósł dopiero kryzys ekonomiczny i liczne perturbacje społeczne, polityczne, kulturowe, wynikłe wskutek zjednoczenia Niemiec $^{25}$. Od wspomnianego momentu zaczęły narastać tendencje do ograniczania napływu „przesiedleńców”, zaostrzania przepisów repatriacyjnych oraz redukcji przyznawanych im ulg, świadczeń, przywilejów ${ }^{26}$.

Ustawa dotycząca przyjmowania przesiedleńców z 28 czerwca 1990 r. (Aussiedleraufnahmegesetz) stanowiła, że liczba „późnych przesiedleńców”, przybywających do RFN w skali roku, ma zostać uzależniona „od ilości opracowanych (pozytywnie zweryfikowanych przez pracowników Federalnego Urzędu Administracyjnego) podań o przyjęcie na terytorium RFN"27. Gwałtowne zmniejszenie napływu „przesiedleńców” z Polski spowodowała ustawa o zakończeniu trwania skutków wojny (Kriegsfolgenbereinigungsgesetz), która weszła w życie 1 stycznia 1993 r. Zakłada ona, że nie istnieje już w Polsce „ucisk” osób pochodzenia niemieckiego, a w związku z tym i presja emigracyjna. „Przesiedleńcy” przybywający do Niemiec są poddawani dokładnemu procesowi weryfikacji niemieckiej przynależności narodowej i muszą udowodnić, że z powodu przyznawania się do niemieckości cierpieli prześladowania. Ograniczono też prawo do sprowadzania do RFN krewnych w ramach łączenia rodzin. Jak zauważa Aleksandra Trzcielińska-Polus, ,zdarza się, że odmawia się przyznania statusu «późnego wysiedleńca» osobom, których krewni posiadają ten status dzięki temu, że wyemigrowali przed $1993 \mathrm{r}$." 28

Mimo drastycznych cięć na początku lat dziewięćdziesiątych XX w. w budżecie federalnym na pomoc integracyjną dla „przesiedlonych”, status „,repatrianta” wciąż upoważnia do korzystania z szeregu przywilejów. Składają się na nie: ulgi finansowe związane z zakupem mieszkania, zasiłki dla bezrobotnych, darmowe kursy językowe, prawo do mieszkania socjalnego, pomoc przy znalezieniu pracy itd. „Przesiedleńcom” oferuje się doradztwo i opiekę socjalną, w którą angażują się (obok państwa) głównie organizacje charytatywne (zapewniające pomoc finansową, kursy informacyjne i językowe, spotkania integracyjne) oraz związki samych przesiedleńców i wypędzonych ${ }^{29}$.

Znacznie większą trudność przysparza rozwiązywanie problemu socjokulturowej integracji nowo przybyłych, rozładowywanie napięć związanych z ich

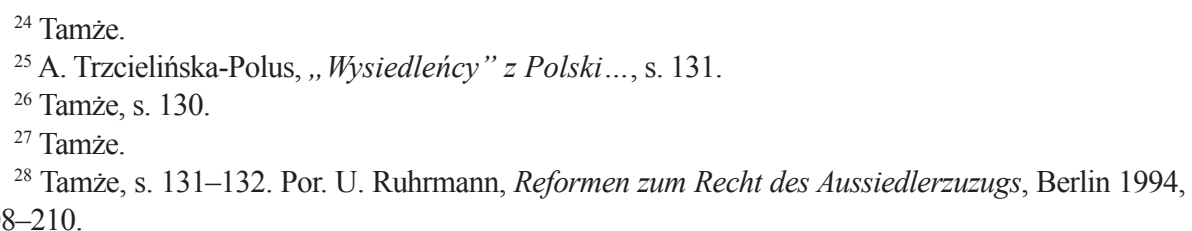
s. $208-210$.

${ }^{29}$ A. Trzcielińska-Polus, „Wysiedleńcy” z Polski..., s. 126; S. Barner, Arbeitsmigranten und Aussiedler. Integration in Theorie und Praxis, Berlin 2007, s. 54-59. 
przebywaniem $\mathrm{w}$ tzw. obozach przejściowych oraz w osiedlach budowanych z myślą o nich. Wiele problemów wynika z nieznajomości języka niemieckiego przez imigrantów, $z$ odczuwanego przez nich poczucia zagubienia wywołanego wyrwaniem z dotychczasowych struktur społecznych. Ich sytuację psychospołeczną pogarsza fakt, że w wielu przypadkach spotykają się z brakiem akceptacji ze strony otoczenia ${ }^{30}$.

Do końca lat osiemdziesiątych XX w. społeczeństwo RFN traktowało „późnych przesiedleńców" ze względną otwartością. Aleksandra Trzcielińska-Polus zauważa, że postawy Niemców wobec nich były bardzo niejednolite. Większość kwestionowała zarówno „niemieckość przybyszów, jak i słuszność przepisów prawnych określających warunki ich przyjmowania (głównie dotyczące pomocy finansowej)". Dość znaczący odsetek społeczeństwa miał wobec nich odczucia ambiwalentne. Znajdowali się jednak także ludzie w pełni solidaryzujący się z polityką przesiedleńczą, deklarujący solidarność, współczucie i chęć pomocy nowo przybyłym $^{31}$.

Jedna trzecia respondentów z RFN i Berlina Zachodniego, według badań Instytutu w Allensbach z listopada 1988 r., nie dostrzegała różnic między „przesiedleńcami" a azylantami. 38\% deklarowało, że uważa ich za Niemców, dla $36 \%$ byli cudzoziemcami, a 26\% nie potrafiło ich zaklasyfikować. Mniej skłonni byli uznać „przesiedleńców” za Niemców przedstawiciele młodszego pokolenia oraz wyborcy SPD i Zielonych, bardziej - ludzie starsi i zwolennicy CDU. Jako zjawisko pozytywne napływ „przesiedleńców” traktowało $22 \%$ ankietowanych, odmiennego zdania było $61 \%$. Charakteryzując „przesiedleńców”, respondenci najwięcej punktów przyznawali trzem opisom: ,jest im ciężko”, „są niepewni i bojaźliwi”, „mówią źle po niemiecku”. Nie brak też było postaw pozytywnych wobec przesiedleńców, chęci udzielenia pomocy, np. w formie przekazania starych mebli czy odzieży, przy wypełnianiu urzędowych formularzy. Dobre zdanie o „przesiedleńcach” mieli często pracodawcy, którzy „,uważali ich za ludzi pracowitych, zdolnych, godzących się na pracę zmianową czy w dni wolne od pracy"32.

Przełom w sposobie postrzegania „późnych przesiedleńców” nastąpił na przełomie lat 1989-1990. W tym właśnie okresie zachodnie Niemcy zalała największa po powojennej fala emigrantów ze wschodu. Efekt, mierzony deklaracjami opinii publicznej, był piorunujący. O ile w 1988 r. ,zaledwie” 66\% społeczeństwa RFN wyrażało wątpliwości co do słuszności przyjmowania tak dużej liczby „przesiedleńców”, o tyle w 1990 r. postawy te, jak zauważa Aleksandra Trzcielińska-Polus, były jawnie agresywne. Powszechne stało się przekonanie, że powodują oni ,nadmierny wzrost wydatków socjalnych, obciążają system ubezpieczeń społecznych, zajmują mieszkania (szczególnie te tańsze - komunalne)

${ }^{30}$ W. Grabe, Górnoślascy „,przesiedleńcy” w Niemczech, [w:] Być Polakiem w Niemczech, red. A. Wolff-Powęska, E. Schulz, Poznań 2000, s. 237.

${ }^{31}$ A. Trzcielińska-Polus, ,, Wysiedleńcy” z Polski..., s. 76.

${ }^{32}$ Tamże, s. $79-80$. 
oraz zwiększają konkurencję na rynku pracy w sytuacji dwumilionowego bezrobocia"33. Badaczka podkreśla, że ,przybywający skarżyli się dziennikarzom, że już od momentu przyjazdu spotykają się z przejawami niezadowolenia, z upokorzeniami i brakiem zrozumienia. Ludzie w ich nowym otoczeniu - twierdzono - są nieskorzy do udzielania pomocy i nastawieni raczej nieprzyjaźnie. W urzędach natomiast klasyfikowano ich jako «Polake» albo «Russki»»" ${ }^{34}$.

Jeszcze bardziej negatywne uczucia funkcjonują wobec ,,późnych przesiedleńców" obecnie. Tym razem jednak ich ostrze jest wymierzone głównie w falę późniejszych wychodźców - „Rosjan”. Również w odniesieniu do nich mówi się, że przesiedleńców jest za dużo, są faworyzowani przez władze, zagrażają statusowi materialnemu miejscowej ludności, dodatkowo zaś, że stanowią zarzewie konfliktów społecznych i „wylęgarnię przestępców”35.

\section{Cztery drogi akulturacji i cztery strategie tożsamościowe}

Strategie tożsamościowe „rosyjskich Niemców” w RFN omówię, bazując na koncepcji czterech dróg akulturacji, sformułowanej przez kanadyjskiego psychologa Johna W. Berry'ego. Swój model oparł na relacji między dwoma współrzędnymi: asymilacją i tożsamością etniczną. W myśl jego założeń stosunki między imigrantami a nowym społeczeństwem układają się na kontinuum: diasporyczność - asymilacja oraz marginalizacja - integralizm ${ }^{36}$. Kontinuum socjalizacyjne imigrantów przebiega zgodnie z logiką słabej lub silnej tolerancji na Inność. Zgodnie z omawianym modelem, za przejaw skrajnej awersji wobec Inności należałoby uznać postawę separacyjną. Przejawia się ona w skłonności imigrantów do samoizolacji w hermetycznym świecie diaspory, rodzi się z ich pogardy wobec kultury, w której żyją, połączonej z mitologizacją tej, w której się wychowali ${ }^{37}$. Janusz Wróbel określił ich mianem ludzi żyjących przeszłością, według wzoru „JA - TAM - PRZEDTEM”, silnie zakorzenionych, lecz bez „skrzydel”38.

Równie wyrazistym przejawem ,zaprogramowania” na nieakceptację Innego jest, moim zdaniem, skłonność emigrantów do (samo)alienacji. Wybierając ją, przybysz nie tylko nie przyswaja systemu wartości i norm kraju, który go przyjął, lecz świadomie odrzuca więź z grupą etniczno-kulturową, w jakiej się wycho-

${ }^{33}$ Tamże, s. 42, 76.

${ }^{34}$ Tamże, s. 77.

${ }^{35}$ T. Lebioda, Niemcy rosyjscy w polityce RFN..., s. 403-420; A. Trzcielińska-Polus, , Wysiedleńcy” z Polski..., s. 81-82.

${ }^{36} \mathrm{~J}$. Wróbel, Podwójne życie Polonusa, czyli ontologia emigranta po 1989 roku, [w:] Emigracja z Polski po 1989 roku, red. B. Klimaszewski, Kraków 2002, s. 142-143.

${ }^{37}$ Zgodnie z definicją Gabriela Sheffera, diaspora to ,etniczna mniejszościowa grupa emigrantów żyjących i działających w kraju ich przyjmującym, którzy jednocześnie utrzymują silne więzy emocjonalne i materialne z krajem swego pochodzenia" - L. Dyczewski, Polacy w Bawarii, Lublin 1993, s. 239.

${ }^{38} \mathrm{~J}$. Wróbel, Podwójne życie Polonusa ..., s. 142-143. 
wał ${ }^{39}$. Negatywnie ustosunkowując się zarówno do nowej, jak i do „starej” kultury, zatraciwszy tradycję, bez zbudowania nowej, staje się on - zgodnie ze słowami Małgorzaty Warchoł-Schlottmann - „człowiekiem marginesu”. Żyje „na skraju dwóch światów: jest częścią obu, lecz nie jest partnerem żadnej, zawieszony pomiędzy dwoma kulturami, dwoma językami, nie czujący się w domu w żadnej z nich"40. Żyje zgodnie ze wzorem nakreślonym przez Janusza Wróbla: „(NIE) JA - NIE TUTAJ/NIE TAM - NIE TERAZ/NIE PRZEDTEM”. Bez korzeni i bez „skrzydeł”41.

Za dowód zamknięcia na Inność uznać można także, paradoksalnie, postawy asymilacyjne, nastawione na pełne wejście w nowe społeczeństwo z zatraceniem odrębności etniczno-kulturowej. Występują one wtedy, gdy imigrant, mając niskie wyobrażenie o własnej grupie etnicznej i kulturze, zrywa kontakty ze współrodakami i wypiera się swych korzeni ${ }^{42}$. W zamian, z gorliwością neofity, w sposób całkowity identyfikuje się z wartościami i wzorami życia obowiązującymi w kraju osiedlenia. Dążąc do asymilacji za wszelką cenę, usiłuje on - jak stwierdza Janusz Wróbel - żyć zgodnie ze wzorem: „JA - TUTAJ - TERAZ”, ze „skrzydłami”, lecz bez korzeni43. Moim zdaniem, bezkrytyczne przyjęcie nowej kultury, połączone z całkowitym wyparciem się kultury rodzimej, niesie ze sobą podobny posmak „fundamentalizmu” i ,ideokracji”, co postawa separacyjna znajdująca się na przeciwnym mu kontinuum.

Skłonność do afirmowania Inności najpełniej odzwierciedla się natomiast w integracyjnych aspiracjach imigrantów. Konwergencja systemów wartości kultury rodzimej i zastanej jest wejściem w nowe społeczeństwo w sposób łączący w zgodną całość elementy własnej grupy etniczno-kulturowej z elementami społeczeństwa przyjmującego. Jak stwierdza Leon Dyczewski, imigrant ,jest wówczas postrzegany jako swój, ale odmienny, lecz nie obcy. Jednostki czy rodziny, które przeszły proces integracji, utrzymują kontakt z krajem swego pochodzenia, a jeżeli został zerwany przez rodziców czy dziadków, ponownie go nawiązują" ${ }^{44}$. Integryści łączą $\mathrm{w}$ ten sposób pozytywne wyobrażenie o nowej kulturze z szacunkiem dla własnej. Prezentują „trzecią wartość”, będącą „kombinacją tego, co najlepsze, w obu źródłach kulturowych". Zgodnie z nakreślonym przez Janusza Wróbla wzorem „JA - TUTAJ poszerzonym o TAM - TERAZ, wzbogaconym o PRZEDTEM”, posiadają zarówno „skrzydła”, jak i korzenie ${ }^{45}$.

$\mathrm{Za}$ istotny kontrapunkt poniższych rozważań można potraktować strategie akulturacyjne emigrantów, w tym „późnych przesiedleńców” z Polski w RFN. Badania przeprowadzone $\mathrm{w}$ środowiskach polonijnych przez różnych ekspertów na przestrzeni ostatnich 25 lat wskazują, że strategie te znacząco ewoluowały

${ }^{39}$ L. Dyczewski, Polacy w Bawarii, s. 239.

${ }^{40}$ M. Warchoł-Schlottmann, Język polski w Niemczech - perspektywy zachowania języka etnicznego u najnowszej emigracji, „Przegląd Polonijny” 1996, nr 3, s. 33.

${ }^{41} \mathrm{~J}$. Wróbel, Podwójne życie Polonusa ..., s. 143.

${ }^{42}$ L. Dyczewski, Polacy w Bawarii, s. 238.

${ }^{43}$ J. Wróbel, Podwójne życie Polonusa ..., s. 142-143.

${ }^{44}$ L. Dyczewski, Polacy w Bawarii, s. 239.

${ }^{45}$ J. Wróbel, Podwójne życie Polonusa ..., s. 142-143. 
- od postaw nakierowanych na separację w diasporze, po tendencje integracyjne, odnotowywane w czasach obecnych. W tym miejscu przywołam tylko konkluzje nasuwające się w związku z badaniami dokonanymi przez Leona Dyczewskiego w 1987 r. oraz przez Martę Guziuk w latach 1999-2003 ${ }^{46}$.

Tabela 1

Strategie tożsamościowe „rosyjskich Niemców”

\begin{tabular}{|l|c|c|c|}
\hline \multirow{2}{*}{ Nazwa strategii } & $\begin{array}{c}\text { Respondenci Leona } \\
\text { Dyczewskiego (1987) }\end{array}$ & \multicolumn{2}{|c|}{ Respondenci Marty Guziuk (1999-2003) } \\
\cline { 2 - 4 } & $\begin{array}{c}\text { \% udziału } \\
\text { respondentów }\end{array}$ & $\begin{array}{c}\text { \% udziału } \\
\text { respondentów } \\
\text { (pierwsze 4 lata na } \\
\text { emigracji) }\end{array}$ & $\begin{array}{c}\text { \% udziału } \\
\text { respondentów } \\
\text { (5-10 rok pobytu } \\
\text { na emigracji) }\end{array}$ \\
\hline SEPARACJA & 60,5 & 11,5 & 4,0 \\
\hline MARGINALIZACJA & 29,9 & 17,5 & 26,5 \\
\hline ASYMILACJA & 3,4 & 9,0 & 27,5 \\
\hline INTEGRACJA & 6,2 & 62,0 & 42,0 \\
\hline
\end{tabular}

Źródło: L. Dyczewski, Polacy w Bawarii, Lublin 1993; M. Guzik, Dwa spojrzenia na problematykę marginalizacji polskich emigrantów w Niemczech, [w:] Wykluczenie i marginalizacja spoteczna. Wokót problemów diagnostycznych i reintegracji psychospołecznej, red. K. Białobrzeska, S. Kawula, Toruń 2006.

W swojej analizie spróbuję wykazać, że strategie tożsamościowe obierane przez współczesnych ,rosyjskich Niemców” w RFN należałoby przyrównać raczej nie do tych, charakterystycznych dla współczesnych „polskich Niemców”, lecz do „Zamkniętych”, „defensywnych” postaw, obserwowanych wśród naszych rodaków w latach osiemdziesiątych.

\section{Русский немец - он и в Германии русский Rosyjskich Niemców recepta na Inność}

Лис мир дизе карте фор унд их заге дир вохер ду коммст - głosi współczesna niemiecka pocztówka, stylizowana na coś między graffiti a tabliczką proszalnego dziada, i poza wesołością prowokuje dylemat. „Przeczytaj mi tę kartkę, a powiem ci, skąd pochodzisz" - jakie odczucia napis ten powinien wywołać w czytelnikach? Jaki cel przyświecał jej autorowi: szyderstwo, autoironia, duma?

${ }^{46}$ L. Dyczewski, Polacy w Bawarii, s. 240; M. Guziuk, Dwa spojrzenia na problematykę marginalizacji polskich emigrantów w Niemczech, [w:] Wykluczenie i marginalizacja społeczna. Wokół problemów diagnostycznych i reintegracji psychospołecznej, red. K. Białobrzeska, S. Kawula, Toruń 2006, s. 107. 
Czy ów dowód na zażyłość z rosyjskością miałby być dla odbiorcy powodem do zadowolenia czy metodą na zdemaskowanie w nim Obcego? Poza mieszkańcami byłej NRD pocztówkę z pewnością odczytają i inni depozytariusze pamięci o „bratniej przyjaźni" z ZSRR, integrujący się w społeczeństwie RFN ze świadomością, że są ,napiętnowani”. Z powodzeniem może być ona również adresowana do rosyjskich Niemców. Czy miły dla nich winien być ów ukłon językowy, tak wyraziście ilustrujący ich dylematy tożsamościowe, ich rosyjsko-radziecko-niemieckie ,zaprogramowanie"? Czy dziedzictwo to jest piętnem skazującym ich na ostracyzm?

Znaczny, jeśli nie największy, odsetek „rosyjskich Niemców” jako formę tożsamościowej strategii adaptacyjnej w RFN wybiera separację kulturową - ,ucieczkę" w rosyjskojęzyczną diasporę, w rosyjskość. Zwartość przesiedleńczych środowisk ogranicza możliwość otwierania się rosyjskich Niemców na wartości, normy obyczajowe, kulturę RFN. Prowadzi często do samoodgraniczania lub wymuszonego odgraniczania „Rusków” przez pozostałych członków wspólnoty od pokus, na jakie narażałby ich kontakt z prawdziwym „niemieckim życiem”.

Znacząca większość „przesiedleńców” dużą wagę przywiązuje do zachowywania tradycji z kraju wychodźstwa, do wierności etnicznym i kulturowym symbolom, które są dla nich niezbywalnym emblematem tożsamości. Cenią sobie rosyjską kuchnię, wyniesiony z ZSRR styl obchodzenia świąt, biesiadowania i kultywowania życia towarzyskiego ${ }^{47}$. Również młodzi przesiedleńcy z krajów WNP postrzegani są jako ludzie pozostający poza obrębem niemieckiej kultury masowej. Czas wolny spędzają najchętniej w sposób praktykowany w rosyjskim kręgu kulturowym: oglądając rosyjskie filmy i TV, słuchając rosyjskiej muzyki, a także praktykując „,męskie rozrywki” w kręgu rosyjskojęzycznych przyjaciół ${ }^{48}$.

Tendencja do alienowania się w rosyjskojęzycznych wspólnotach połączona jest natomiast $\mathrm{z}$ traktowaniem przez rosyjskich Niemców za główne kryterium oceny innych i siebie... ideału „niemieckości”, choć specyficznie rozumianej. Przesiedleńcy z rozgoryczeniem przyjmują fakt niedorastania autochtonów do wzorca niemieckości definiowanego niezmiennie przez pryzmat cnót, takich jak „czystość”, „pracowitość”, „uczciwość”, traktowanych jako nieodzowny atrybut „bycia Niemcem”. Krytycznie odnoszą się do obserwowanego w RFN „kryzysu autorytetów" i ,upadku moralności”. Obserwacje te nie prowadzą przesiedleńców do przedefiniowania pojęcia „niemieckości”. Przeciwnie, sprawiają one, że rosyjscy Niemcy traktują nową ojczyznę jako kraj zmieniony przez cudzoziemców, tracący bezpowrotnie niemiecką tożsamość. Stąd stosują dyskurs oparty na

${ }^{47}$ I. Graudenz, R. Römhild, Grenzerfahrungen. Deutschstämmige Migranten aus Polen und der ehemaligen Sowjetunion im Vergleich, [w:] Forschungsfeld Aussiedler. Ansichten aus Deutschland, red. I. Graudenz, R. Römhild, Frankfurt am Main-Berlin-Bern-New York-Paris-Wien 1995, s. $60-61$.

48 R. Giest-Warsewa, Sich durchs Leben boxen. Annäherungen an Alltagswelten und Gewalterfahrungen junger Spätaussiedler, [w:] Psychosoziale Betreunng und psychiatrische Behandlung von Spätaussiedlern, red. J. Collatz, T. Heise, Berlin 2002, s. 115-116. 
idei „świata na opak”: nie przesiedleńcy, lecz ludność miejscowa zostaje wpisana w kategorię „obcych Niemców”. To rosyjscy Niemcy są w istocie „,prawdziwymi”, „lepszymi Niemcami”49. Szczególnie ludzie starzy silnie „odstają” od otoczenia nie tylko mentalnością, lecz także wyglądem i ubiorem. Łatwa w identyfikacji jest zwłaszcza społeczność babuszek. W odróżnieniu od swoich rówieśniczek-Niemek, w miejscach publicznych noszą na głowach ludowe chusty. Stanowią one nie tylko ich tradycyjny element stroju, lecz, moim zdaniem, przede wszystkim symbol odrębności kulturowej. Pokazując się w nich, ,rosyjskie Niemki” dają do zrozumienia, że współczesny ,niemiecki model życia” nie jest tym, do którego aspirują ${ }^{50}$.

Jako wyrazisty przykład postaw nastawionych na zachowanie tożsamości diasporycznej posłużyć może sposób zachowań i myślenia cechujący „późnych przesiedleńców” należących do protestanckich wspólnot „wolnych Kościołów”, do których zaliczane są m. in. wspólnoty menonickie. Do czasów obecnych, członków związanych z nimi bractw obowiązuje szereg ściśle przestrzeganych norm, takich jak: zakaz palenia tytoniu i picia alkoholu, uprawiania hazardu, powściągliwość w oglądaniu TV, chodzeniu do kina i teatru. Poza tym, braci obowiązuje zakaz noszenia krawatów, jako oznak marnej doczesności, kobiety zaś - zakaz noszenia spodni i obcinania włosów, które muszą nosić pod chustą przynajmniej w czasie nabożeństw ${ }^{51}$. Wśród „późnych przesiedleńców”, wywodzących się z ich środowisk, znacząco niższy jest odsetek osób, które ,zeszły na złą drogę”, kryminalistów oraz uzależnionych od narkotyków i alkoholu. To właśnie im łatwiej jest zachować poczucie ciągłości. Jej gwarancję daje im: sens życia - przez wiarę, oraz stabilność i bezpieczeństwo - przez stały kontakt i stosowanie się do zaleceń wspólnoty ${ }^{52}$. Rzadkie są również wśród nich postawy integracyjne oraz asymilacyjne.

Stygmatyzacja jako „Niemiec”, dokonywana przez administrację radziecką, zyskiwała w ZSRR (i zyskuje nadal w krajach WNP) rangę determinującego przyszłość jej depozytariusza, znamienia. W ten sposób, stwierdza Rudolf Rahn, niemiecką narodowość przypisaną mieli zarówno mieszkańcy ZSRR uważający się za Niemców, poczuwający się do związków z niemiecką kulturą, jak i osoby niemieckiego pochodzenia socjalizowane w „duchu radzieckim”, uważające się za Rosjan. Te ostatnie niemiecką narodowość wpisaną w paszporcie traktowały

${ }^{49}$ I. Graudenz, R. Römhild, Grenzerfahrungen, s. 60-61.

${ }^{50}$ J. Ardagh, Germany and Germans, London 1995, s. 288.

${ }^{51}$ G. Stricker, Die lutherische „Brüderbewegung“ in Russland als Echo des europäischen Pietismus, [w:] Die Russlanddeutschen in Russland und Deutschland: Selbstbilder, Fremdbilder, Aspekte der Wirklichkeit, red. E. Barbasina, Essen 1994, s. 41; S. Theis, Religiosität von Russlanddeutschen, Stuttgart 2006, s. 134-136.

${ }_{52}$ R. Rahn, Hintergründe, Konflikte und Bewältigungsstrategien bei Migranten aus dem russischsprachigen Raum sowie Interventionen nach der positiven Psychotherapie, [w:] Psychosoziale Betreuung und psychiatrische Behandlung von Spätaussiedlern, red. J. Collatz, T. Heise, Berlin 2002, s. 209-210. 
najczęściej jako niewygodny szczegół z życiorysu, zamykający im, w kraju „zwycięskiego socjalizmu", drogę do kariery w wielu zawodach. Rozbieżność między rosyjską tożsamością etniczną a oficjalnym przypisaniem do narodu niemieckiego szczególnie wyraziście można było zaobserwować u dzieci pochodzących z rodzin mieszanych etnicznie ${ }^{53}$.

Zgodnie z założeniami polityki narodowościowej obowiązującej w ZSRR każda grupa etniczna posiadała własne terytorium autonomiczne, na obszarze którego jej przedstawiciele byli ludnością politycznie i społecznie uprzywilejowaną. Zasada ta, od $1941 \mathrm{r}$. aż do rozpadu ZSRR, w praktyce czyniła wyjątek tylko dla jednej znaczącej mniejszości narodowej - Niemców. Jedynym spoczywającym na barkach jej członków „,przywilejem” było postępowanie zgodnie z dewizą: „pracuj tak ciężko i wydajnie, by stać się niezastąpionym". Ekstrapolując sytuację znaną z ZSRR, rosyjscy Niemcy przybywali do RFN jako do własnego, należnego im kraju. Po przesiedleniu z tym większym oburzeniem odkrywali więc, że na obszarze ich nowej ojczyzny zamieszkuje ogromna rzesza cudzoziemców dysponujących, w porównaniu ze standardami obowiązującymi w Kraju Rad, zdecydowanie zbyt szeroką paletą przywilejów i swobód. W opinii Rudolfa Rahna, reakcja ta nie jest dowodem na cechujący „późnych przesiedleńców” nacjonalizm. Stanowi ona jedynie świadectwo przejawianego przez nich zapotrzebowania na sprawiedliwość rozumianą w duchu radzieckim ${ }^{54}$.

Rogers Brubaker podkreśla monopolizującą, „zawłaszczającą” rolę, jaką w ZSRR odgrywał język i kultura rosyjska jako nierozerwalny komponent i wyraziciel radzieckiej kultury, mentalności i ideologii. To właśnie język rosyjski stał się lingua franca dla wszystkich wymieszanych etnicznie i kulturowo mieszkańców ZSRR, Rosjanie zaś - narodem „przodującym” w sowieckim imperium ${ }^{55}$. Jedynie niewielu mieszkańców Kraju Rad znało język autochtonów będących oficjalnymi gospodarzami autonomicznych republik i terytoriów. Tylko nieliczni nie-autochtoni interesowali się kulturą i historią obszarów, na których urodzili się i dorastali. Na tym właśnie podłożu wykształciła się niechęć wobec nich ze strony miejscowych. Brak doświadczeń związanych z rzeczywistym „wżyciem się” w wielokulturowość stanowi współcześnie poważny problem w procesie akulturowania się „późnych przesiedleńców” z krajów WNP w rzeczywistość niemiecką ${ }^{56}$.

Rudolf Rahn zauważa, że rosyjscy Niemcy mają skłonność do atrybucji własnych lęków na Obcych. W związku ze wspomnianym syndromem pojawiają się u nich tendencje do szafowania oskarżeniami wobec siebie i innych, do poważnych zaburzeń nastrojów, idealizacji przeszłości. Przejawiają także tendencję do

${ }^{53}$ Tamże, s. 198.

${ }^{54}$ Tamże.

${ }^{55}$ R. Brubaker, Nacjonalizm inaczej. Struktura narodowa i kwestie narodowe w nowej Europie, tłum. J. Łuczyński, Warszawa-Kraków 1998, s. 35-36.

${ }^{56}$ R. Rahn, Hintergründe, Konflikte und Bewältigungsstrategien bei Migranten..., s. 200. 
nieuzasadnionego generalizowania, znajdującą wyraz w oddawaniu się we władzę agresji, izolacji społecznej, a także przesądów i stereotypów ${ }^{57}$. Badacz powołuje się na tezę, zgodnie z którą mentalność radziecka opierała się na skłonności do syntetyzowania. Objawiała się ona w tworzeniu zideologizowanego obrazu dziejów jako drogi wiodącej z mroków niewartej zapamiętania przeszłości w świetlaną przyszłość, ku której wiedzie heroiczna i piękna, przynajmniej dla obywateli krajów „demokracji ludowej”, teraźniejszość. Mentalność ta, po przybyciu „późnych przesiedleńców” do RFN, została poddana traumatycznej próbie. Jednowymiarowy, nieznoszący niuansów światopogląd stymuluje nasilanie się wśród rosyjskich Niemców wielorakich objawów świadczących o ich małej otwartości na sytuacje ambiwalentne. Należą do nich: niechęć i lęk wobec zmian, potrzeba zachowania status quo, uzależnienie od poglądów innych, potrzeba mimikry. Ich rezultatem jest skłonność do wypierania „czarnych plam” z własnej świadomości historycznej, a nawet negowanie przeszłości - własnej i zbiorowej. Mała elastyczność rosyjskich Niemców i konserwatyzm przejawianych przez nich zachowań skutkuje trudnością w przezwyciężaniu konfliktów międzypokoleniowych ${ }^{58}$.

Rahn podkreśla silne zapotrzebowanie mieszkańców ZSRR na poczucie stabilności życiowej. Popularne wyrażenia, takie jak „twardy jak stal”, „kryształowo czysty”, „niezłomny”, traktowano w rzeczywistości radzieckiej jako niezbędny zestaw przymiotów mających charakteryzować bohaterów narodowych, lecz także przyjaciół, współpracowników, członków rodziny. Jako jedną z największych cnót kultywowano więc nietolerancję, volens nolens. Była ona wymierzona nie tylko we „wrogów ludu”, lecz we wszelkie „błędy i wypaczenia” 59 .

W historiozoficznych schematach autonarracyjnych przesiedleńcy ze średniego pokolenia posługują się często metaforą „raju utraconego”. Jej ucieleśnieniem są powieści rosyjskiej Niemki Tiny Rin pisane „ku pokrzepieniu serc”. W opowiadaniu ,, Tabor" idzie za granice dzieje przesiedleńców zostały przez nią podzielone na następujące etapy: szczęśliwe życie w Rosji, emigracja do RFN, rozczarowanie nową ojczyzną, nostalgia, dylemat - dalsze próby integracji czy powrót do domu. Prześledźmy kluczowe momenty fabularne zawarte w tym opowiadaniu.

„Była ich nieprzebrana ilość. Wielki ród bliskich i dalszych krewniaków. Klan. Rozprzestrzenił się praktycznie na całym terytorium obwodu saratowskie$\mathrm{go}^{60}$. [...] Starsze pokolenie z całych sił starało się chronić narodowe tradycje, przekazywać je wzrastającym młodym «pędom». Jednak z biegiem lat krzepki «tabor» zaczął przeżywać zmiany, stopniowo się umiędzynarodawiał. [...]

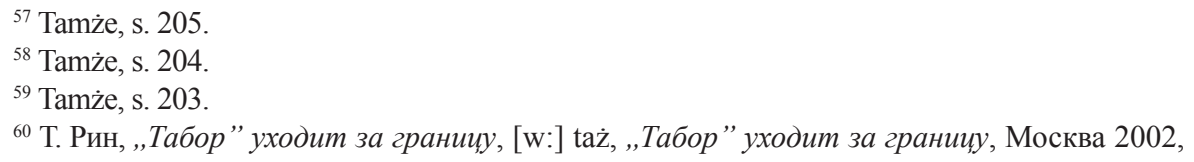


W krew wchodziły, zakorzeniały się, umacniały i stawały własnymi cechy charakteru, swoiste dla mieszkańców tej ziemi, na której oni, tak zwani rosyjscy Niemcy, wzrośli. A ziemia rosyjska, która przyjęła ich rodziców i dziadów, była dobra, urodzajna, gościnna. I ludzie rosyjscy, którzy dali schronienie pierwszym Niemcom, byli weseli, serdeczni, wrażliwi na cudzą biedę, gotowi zdjąć ostatnią koszulę i oddać potrzebującemu, podzielić się z bliźnim ostatnim kęsem chleba ${ }^{61}$. [...]

Tak mijały lata. Kłócili się, wojowali, godzili, po równo dzielili biedę, radości i niedole. Zdawałoby się, że tak było i będzie zawsze. Że nic nie będzie już w stanie zmienić ich ustatkowanego, szczęśliwego życia"62.

„Nagle - szok. Jego winowajcą był Dieter Müller. [...] To on jako pierwszy $z$ rodu wyjechał w turystyczną podróż do Berlina ${ }^{63}$. [...] Drugi szok spadł niczym grom z jasnego nieba [...], gdy do Niemiec, [...], wyjechał Helmut z żoną" ${ }^{64}$. Po nim - jego siostra i jej synowie z rodzinami. „I ruszył «tabor» za granicę...”

„Smutne wieści od przebywających w niemieckiej ojczyźnie krewniaków wywołały spadek entuzjazmu i osłabiły pokusę szybkiej przeprowadzki do Niemiec u tych, którzy pozostali jeszcze w Konstantynowce” ${ }^{65}$. „Pod względem materialnym prawie wszyscy z konstantynowskiego «taboru» żyją dostatnio. Wszyscy czują jednak, że są tam obcy. Rdzenni, prawdziwi Niemcy uważają naszych za trzeci sort. [...] Pierwszy - to Niemcy zachodni, drugi - Niemcy wschodni, z byłej NRD, no a trzeci - nasi, rosyjscy Niemcy"66.

Gorycz zawarta w tym stwierdzeniu nie dziwi, biorąc pod uwagę, że również chociażby imigranci z Polski w RFN formułują dyskurs podkreślający niższość kulturową rosyjskich Niemców, ich zacofanie cywilizacyjne. Krzysztof Maria Załuski, zjadliwy krytyk polskich emigrantów na Zachodzie, w następujący sposób zilustrował „późnych przesiedleńców” początku lat dziewięćdziesiątych oczami „Niemca polskiego”: „Ostatnio poza polskimi Niemcami do obozów przejściowych napływają także sowieccy uchodźcy. Tak zwani Niemcy Nadwołżańscy przewożeni są transportami wprost z lotnisk. [...] Wielu z nich we Friedlandzie po raz pierwszy styka się z toaletami. Zdarzało się, że kobiety myły w muszlach dzieci albo płukały w nich włosy. Załatwiały się natomiast w krzakach za barakiem. Doszło do tego, że władze obozu musiały na drzwiach toalet umieścić «instrukcje obsługi» papieru toaletowego i podpasek" ${ }^{\prime 67}$.

Julia, bohaterka opowiadania Rin Bilet w jedna stronę, powie: „W żaden sposób nie mogę zrozumieć, dlaczego my, ludzie rozumni, ulegliśmy owczemu pędowi i w ślad za innymi rzuciliśmy się do Niemiec. [...] Rzucili wszystko, co

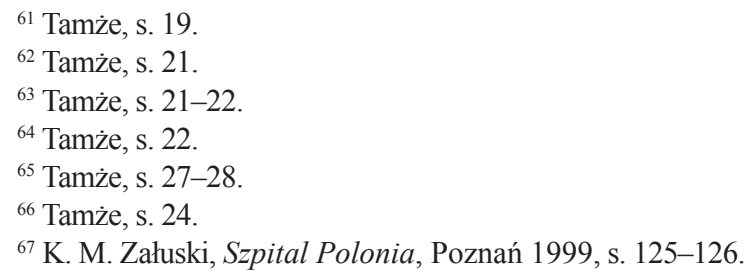


było nam drogie, i popędzili tutaj, jak na spotkanie ze szczęściem" ${ }^{68}$. W jej ujęciu Zachód to - cytując komentarz Tadeusza Klimowicza do poglądów Aleksandra Sołżenicyna - „nowy Babilon, Sodoma i Gomora, ale nigdy nowa Arkadia czy Atlantyda. [...] Brakuje w nim Wielkiej Idei”"69. Julia stwierdza: „Poznałam [...] wielu rówieśników. To są jednak kompletnie obcy mi ludzie. Większość z nich interesują tylko horoskopy, przepowiednie, podwyżki i obniżki cen w sklepach, sezonowe wyprzedaże oraz rozstrzygnięcie problemu, jak najekonomiczniej przeżyć najbliższy miesiąc. [...] Książek moje rówieśniczki [...] praktycznie nie czytają. Zresztą, rosyjskie Niemki po przyjeździe tutaj również bardzo szybko przestają czytać, a co za tym idzie także myśleć. Nic nie zaprząta im głowy. [...] Wydaje się, że zrobiłam wszystko, by się przystosować. A w rezultacie w moim dwupokojowym mieszkaniu jestem tylko ja i książki. I muzyka. Rosyjska" "70.

Przekazywanie pamięci o utraconej ojczyźnie, kultywowanie spuścizny przodków jest jedyną metodą obrony własnej tożsamości na obczyźnie: „Teraz martwimy się tylko o to, by [nasze dzieci] nie zapomniały języka rosyjskiego i zachowały to, co najlepsze, z naszego życia w Rosji. I opowiedziały potem swoim dzieciom o tej chlubnej karcie z historii niemieckiego narodu. Przejdą lata i oczywiście wiele wywietrzeje z pamięci! Takie jest życie. Odejdzie w przeszłość samo pojęcie «rosyjski Niemiec» $\rangle^{71}$. Ja wierzę jednak [...], że może chociaż poprzez geny przekazane zostaną z pokolenia na pokolenie te cechy rosyjskiego narodu, które weszły w krew Niemców w czasach, gdy żyli na ziemi rosyjskiej”’72.

\section{Tożsamość asymilacyjna RFN jako „raj odzyskany”}

Przeciwieństwem postaw nakierowanych na całkowite odizolowanie się od niemieckiego społeczeństwa, są - również występujące w środowisku ,późnych przesiedleńców" $z$ byłego ZSRR - dążenia asymilacyjne. Z jednej strony, wiąże się to $\mathrm{z}$ faktem, że do głównych komponentów tożsamości akcentowanych w autonarracjach ludzi pamiętających II wojnę światową należy konstruowanie wizji ZSRR jako „niewoli babilońskiej”, piekła oraz RFN jako raju odzyskanego. Patos tych narracji dobrze oddają tytuły rozliczeniowych książek i opowiadań: Będziemy pyłem na wietrze ${ }^{73}$, W poszukiwaniu ojczyzny ${ }^{74}$. $\mathrm{Z}$ drugiej strony, wiąże się to

${ }^{68}$ Т. Рин, Билет в одну сторону, [w:] taż, „Табор”..., s. 353-354.

${ }^{69}$ T. Klimowicz, Solżenicyn - ostatni sprawiedliwy, „Gazeta Wyborcza”, 05.12.2003, http://www. niniwa2. cba.pl/solzenicyn_ostatni_sprawiedliwy.htm.

${ }^{70}$ Т. Рин, Билет..., s. 358.

${ }^{71}$ Т. Рин, „Табор”..., s. 29.

${ }^{72}$ Tamże.

${ }^{73}$ E. Schoppert, Wir werden Staub im Wind.

${ }^{74}$ R. H. Walth, Auf der Suche nach Heimat. 
ze zjawiskiem „nawrócenia” na niemieckość rosyjskich małżonków, zwłaszcza mężów, lub dzieci z małżeństw mieszanych „późnych przesiedleńców”. Ludzie ci, powodowani „sowiecką mentalnością”, z jej naczelną zasadą niewyróżniania się i wtapiania w thum, starają się, zewnętrznie i wewnętrznie, przekształcić w „etnicznych Niemców”. W tym celu całe rodziny zmieniają rosyjsko brzmiące nazwiska na niemieckie, np. po matce lub żonie, rosyjskie imiona zastępują niemieckimi, z wyznania prawosławnego dokonują konwersji na protestantyzm lub katolicyzm, a rosyjską narodowość w paszporcie zamieniają na niemiecką ${ }^{75}$.

\section{W piekle wykorzenienia}

W wielu wywiadach przeprowadzonych współcześnie wśród rosyjskich Niemców, należących do średniego i najmłodszego pokolenia, na pytanie o motywy przyjazdu do RFN często odpowiadają oni: „Przede wszystkim chodziło o wyjazd s t a m t ą d". Dopiero w dalszej kolejności - o znalezienie się g d z i e i n d z i e j ${ }^{76}$. Karl-Markus Gauß w następujący sposób wypowiada się o tożsamości etniczno-kulturowej cechującej Niemców z Kazachstanu, którzy wyemigrowali do Odessy, traktując ją jako trampolinę w drodze na Zachód: „Prawie w całej Europie, gdziekolwiek odwiedzałem zagrożone mniejszości narodowe, ich języka, obrzędów i zwyczajów strzegli zdecydowanie chłopi, a pośród nich zwłaszcza kobiety zobowiązane do utrzymywania ogniska domowego i wychowywania dzieci. Ci zaś, którzy szli za pracą do wielkich miast, zarzucali tradycję [...] - kulturalny i językowy związek z mniejszością, z której się wywodzili i dla której byli w ten sposób straceni. Tutaj, nad Morzem Czarnym, wyglądało to całkiem odwrotnie: wykształceni mieszczanie zachowali swoją mowę niemiecką i pielęgnowali resztki niemieckiej kultury, a ludzie deportowani na wieś utracili w osiedlach kazachskich i jedno, i drugie" 77 .

W tym kontekście nie dziwi, że znaczący odsetek „,przesiedleńczych” środowisk boryka się z problemem tożsamościowego chaosu, który prowadzi ich do zaniku tradycji etnicznych i wykorzenienia kulturowego. Utrata „wewnętrznego kompasu" odzwierciedla się w skłonności opisywanych grup do bujnego życia towarzyskiego, samooskarżania się, popadania $\mathrm{w}$ depresję ${ }^{78}$. Wymienione czynniki popychają rosyjskich Niemców ku marginalizacji społecznej, która objawia się w pauperyzacji i wszelkiego typu patologiach. Należą do nich zwłaszcza alkoholizm, narkomania oraz wysoka przestępczość, cechujące środowiska „prze-

\footnotetext{
${ }^{75}$ R. Rahn, Hintergründe, Konflikte und Bewältigungsstrategien bei Migranten ..., s. 198.

${ }^{76}$ Tamże, s. 195.

${ }^{77}$ K.-M. Gauß, Niemcy na peryferiach Europy. Wędrówki przez Litwę, Spisz i brzegiem Morza Czarnego, thum. S. Lisiecka, Wołowiec 2008, s. 212-213.

${ }^{78}$ R. Rahn, Hintergründe, Konflikte und Bewältigungsstrategien bei Migranten ..., s. 205.
} 
siedleńcze"79. Z analizy przeprowadzonej w roku 2000 przez Federalny Urząd Kryminalny Baden-Würtemberg wynika, że ,,późni przesiedleńcy” z krajów WNP zajmują eksponowane miejsca w niemieckich statystykach zgonów wywołanych przez narkotyki. Rudi Giest-Warsewa stawia tezę, że narkotyki pełnią wśród omawianej grupy młodzieży nie tyle funkcję symboliczną lub socjalizacyjną, ile stanowią środek służący thumieniu frustracji spowodowanej życiem w Niemczech ${ }^{80}$. Rosyjscy Niemcy przodują również w niemieckich statystykach leczonych w trybie przewlekłym alkoholików ${ }^{81}$.

Za sprawą wymienionych patologii w społeczeństwie niemieckim funkcjonuje stereotyp rosyjskich Niemców jako kryminalistów, pijaków i narkomanów. Słuszność tych sądów zdaje się potwierdzać bulwersująca historia bezrobotnego rosyjskiego Niemca Alexa Wiensa. W lipcu 2009 r. 28-latek zasztyletował na sali sądowej w Dreźnie Marwę al-Sherbini, 31-letnią Egipcjankę będącą w 3 miesiącu ciąży, która zeznawała przeciw niemu w sprawie o znieważenie na tle rasistowskim. Mężczyzna nazwał kobietę , islamistką" i „terrorystką” po tym, jak poprosiła go ona o ustąpienie miejsca na huśtawce na placu zabaw jej trzyletniemu synowi ${ }^{82}$. Historia ta $\mathrm{w}$ skrajnej formie odzwierciedla ksenofobiczne i rasistowskie postawy oraz zachowania, typowe, niestety, dla zmarginalizowanych ,przesiedleńczych" środowisk.

\section{Meine russische Nachbarn „Rosyjskich Niemców” zdolności integracyjne}

Równocześnie należy podkreślić, że w społeczności rosyjskich Niemców narodził się szereg adaptacyjnych i integracyjnych success stories. Harmonijna, rosyjsko-niemiecka tożsamość, połączona ze zdolnością do życia w obu kulturach i odczuwania dumy z przynależności do nich cechuje przede wszystkim przedstawicieli najmłodszego pokolenia „przesiedleńców”, którzy przybyli do RFN w dzieciństwie, przed pełnym akulturowaniem się w kraju wychodźstwa. Staje się ona również udziałem ludzi przyjmujących otwartą postawę wobec świata oraz zdolnych do postaw autoironicznych i twórczych. Za dobry przykład mogą posłużyć chociażby całkiem liczni artyści, piosenkarze, literaci, którym w Rosji i Niemczech udaje się dobrze „sprzedać” własną wielokulturowość. Należy do nich chociażby wspomniana już rosyjska Niemka Tina Rin czy - dodajmy

${ }^{79}$ Tamże, s. 195.

${ }^{80}$ R. Giest-Warsewa, Sich durchs Leben boxen, s. 116-117.

${ }^{81}$ J. J. Lessmann, B. Bätz, A. Prager-Andresen, Besondere Aspekte der Suchterkrankungen und -behandlung bei Aussiedlern, [w:] Psychosoziale Betreuung und psychiatrische Behandlung von Spätaussiedlern, red. J. Collatz, T. Heise, Berlin 2002, s. 244.

${ }^{82}$ R. Alexander, Von Kopftücher und Vorurteilen, http://www.welt.de/wams_print/article4147120/Von-Kopftuechern-und-Vorurteilen.html. 
na marginesie - przybyły do RFN na analogicznych jak rosyjscy Niemcy zasadach rosyjski Żyd Wladimir Kaminer, pisarz niezwykle popularny w Niemczech. Zalicza się też do nich bez wątpienia autoironicznie traktujących swe kulturowe dziedzictwo twórców portali poświęconych problematyce „przesiedleńców” oraz prześmiewczych anegdot, których bohaterami są z reguły dumne ze swej archaicznej niemczyzny babcie i ośmieszający się mimo woli, pozujący na ,prawdziwych Niemców" neofici kulturowi ${ }^{83}$. Treść tych anegdot dowodzi, że kluczem do integracji ,przesiedleńców” jest zdolność do trafnego diagnozowania kontekstów kulturowych połączona z adekwatnym dostosowywaniem postaw i zachowań. $\mathrm{W}$ jednym $\mathrm{z}$ dowcipów krążących $\mathrm{w}$ środowisku rosyjskich Niemców przedsiębiorca-przesiedleniec pyta żony:

- Gdzie jest mój stary, podarty, poplamiony garnitur?

- Wyrzuciłam do śmieci.

- Coś ty zrobiła! W czym ja teraz pójdę do Urzędu Skarbowego? ${ }^{84}$

\footnotetext{
${ }^{83}$ A. Reiser, R. Schultz, 99 Anekdoten von Aussiedlern, s. 81.

${ }^{84}$ Tamże, s. 87.
} 